\title{
The Year 1979 as a Turning Point in Syrian Theatre: From Politicization to Critical Humanism
}

\section{Friederike Pannewick}

This chapter will reflect on the year 1979 as a turning point in Arab theater, taking Syrian playwright Sa dallāh Wannūs as a case study. This internationally acclaimed author, born in 1941, belonged to a generation of Arab intellectuals and artists whose political and artistic self-definition and worldview was strongly shaped by the Palestine conflict. Wannūs's early works reveal an intense social engagement, which he characterized as a "theater of politicization/masrah al-tasȳ̄s" (Wannūs 1996, p. 131). But his self-positioning as a politically engaged artist was not static throughout the latter part of his life, which was cut short by illness and ended when he was only 56 years old in 1997. Nearly twenty years earlier, in 1979, his political and literary convictions were seriously called into question by an event that interrupted his life and writing and interfered with his artistic production. In an extensive interview at the end of his life, he characterized this event as decisive turning point in his dramatical writings.

According to narrative psychologist Jerome Bruner, turning points in individual life stories, 'though they may be linked to things happening 'outside,' are finally attributed to a happening 'inside' - a new belief, new courage, moral disgust, 'having had enough"” (Bruner, quoted in Nünning and Sicks 2012, p. 8). This means that change in society goes hand in hand with personal transformations. Reaching a turning point "tends to result in, and correlate with, a heightened degree of self-awareness or self-consciousness on the part of the subject in question, an increased awareness that a decision has to be made" (Nünning and Sicks 2012, p. 7). The study of turning points looks for concurrences and dis-

\footnotetext{
F. Pannewick $(\bowtie)$

Centrum für Nah- und Mittelost Studien, Philipps-Universität Marburg, Marburg, Germany

e-mail: pannewick@uni-marburg.des
} 
continuities beyond conceptions of time in terms of linearity (Nünning and Sicks 2012, p. 17).

The term "turning point" is understood here according to Nünning and Sicks's definition as "mininarration" and "metaphor" (Nünning and Sicks 2012, p. 7) inasmuch as turning points have a narrative character and "tend to interrupt regular patterns and trajectories in the life-flow" (Abott, quoted in Nünning and Sicks 2012, p. 7). The narrative character points at the fact that turning points are not objective givens "but are instead conceptualized as results of retrospective constructions of meaning" (Nünning and Sicks 2012, p. 2).

The decisive turning point in Wannūs's literary career was the day of November 19, 1977 when President Sadat became the first Arab politician to visit Israel on official business, where he outlined his plans for peace in a speech to the Israeli Knesset (parliament). A world came crushing down for Wannūs. This unilateral peace offer, which led to the Camp David Accords of 1978 and resulted in the Egypt-Israel peace treaty signed in 1979, left the two key issues unanswered: the situation of the Palestinian refugees and the status of Jerusalem and the occupied territories. A comprehensive and coherent solution to the Israel-Palestine conflict seemed thus to recede into the distance. Wannūs tried to take his own life on the night of this epochal event. He stopped writing plays and would not complete any for more than ten years.

This chapter will show how the writings he published after this self-imposed silence turned away from a didactic theatre of politicization to psychological studies focusing on the individual, as well as minority and gender issues, which might be considered part of what Fadi Bardawil described as an "inward turn" (2013, p. 1). This new literary style was as politically engaged as his previous style, but this political commitment is conveyed differently, arguing in favor of a new and critical humanism in a Saidian understanding whereby humanism is based on "the agency of human individuality and subjective intuition rather than on received ideas and approved authorities" (Abraham 2007, p. 5).

In the Syrian documentary film Wa-hunaka ashyä' kathïra kāna yumkin an yatahaddath 'anhā al-mar' [There Are So Many Things Still to Say], directed by Omar Amiralay and broadcast by La Sept/Arte in 1997, Wannūs speaks about this crucial turning point in his dramatist's life and work:

When Sadat visited Israel, I can't describe my feelings. There was some astonishment although I can't say the visit surprised me. The sun was bright that day, even though I was shut up in this very room behind my desk. I closed all the inner and outer windows. I felt the sun was entering through the cracks in the windows and entering the sitting room. Like a foreign aggression against my inner peace. I sat and wrote (The Coffin and the Mourners Together). It was the last thing I 
wrote before a long period of silence. After I finished writing it, I said "I'm tired" and I should go rest for a few weeks, some place, in Lattakia or Aleppo. But I was very nervous and knew I couldn't control myself. It was around sunset, I took a sleeping pill, trying to escape through sleep. Two hours later, I woke up, even more nervous and troubled. The darkness was total. That night, I made a serious attempt to commit suicide. (Wannūs in Amiralay 1997, min. 25:14-28:50).

This impressive and touching testimony from one of the most important dramatists of modern Arabic theatre tells us about an individual and political turning point in the late 1970s. If we assume that something fundamental changed at this time, we might ask: what was this change about? And what about the notion of the political aspect of the arts - did it remain the same after this turning point in 1979 and then later, in the 1980s and 1990s as Wannūs and others of his generation changed their literary styles, abandoning an aesthetic of politicization in favor of a call for critical humanism?

\section{Politicization and Commitment in the Wake of 1967}

International in his orientation, Wannūs was an intellectual who saw himself as part of a worldwide avant-garde movement. The early period of his writing, from the early 1960s to the late 1970s, was formatively influenced by Erwin Piscator's political theatre, but above all by Bertolt Brecht's didactic drama. Wannūs' initial works reveal an intensive social engagement, which he characterized in his theatre manifesto Bayanāt li-masraḥ 'arabī jadīd, published in 1970, as a "theatre of politicization or masrah al-tasȳ̄s" (Wannūs 1996, vol. 3; cf. also vol. 1, p. 131). In a phase marked by significant social developments that were triggered by the country's defeat by Israel, Wannūs provocatively formulated the lineaments of a "politicizing" aesthetic which was to make Arab theatre into a vehicle of hope, instigating political reforms and undergirding processes of democratization: "We perform theatre to develop and change consciousness. We want to deepen the grasp of our collective consciousness for our shared historical consciousness" (Wannūs 1970, p. 24).

It is noteworthy that the June war of 1967 did not trigger resignation or despair in this dramatist's work. On the contrary, in the wake of the all-embracing hazima (defeat), he conceptualized his theatre of politicization. His play Haflat samar min ajl khamsat huzayrān (An Entertainment Evening for June 5), published shortly after the 1967 defeat, stages.

The profound malaise of a majority of Arabs in the aftermath of the 1967 war: people overwhelmed by humiliation, disappointment, anger, and fear. With 
his inimitable honesty and lucidity, he depicts a malaise caused primarily, in his opinion, by state repression and manifested in military defeat, but also in cultural mediocrity, intellectual futility, and personal despair. (Kassab 2010, p. 53).

The articulation of his concept of "politicizing theater" is thus to be seen in the context of Wannūs's devastating critique of the political and intellectual situation in 1967. Given that theater was an important domain for cultural critique, Wannūs developed the lineaments of a "politicizing" aesthetic within this realm.

\section{Between Commitment and Despair}

However, this rather optimistic and somewhat idealistic perspective changed significantly due to the gloomy political circumstances in the Middle East. Throughout the late 1970s and the 1980s, Wannūs had been imbued with such a strong sense of living through a crisis that it encroached upon and damaged his entire personal life, an affect he emphasized repeatedly in various statements. One of these statements is the interview with Omar Amiralay in the documentary quoted above. Another revealing text in this regard is a short piece Wannūs wrote after Sadat's visit to Israel: "Anā l-janāza wa-l-mushayyi 'ūna" ["I am the Deceased and the Mourners"] (1996, vol. 3, p. 439 ff.). Here, politicizing art seems to have lost its validity, the individual is cut in two parts while one observes the funeral of the other:

My life has neared its end and I still dream of saying "No." I wanted and I want to say "No" to the "Yes" citizen, to the prison-homeland, to the modernization of the methods of torture and domestication, to the official discourse. ... I wanted and I want to say "No." And I search for my tongue but find only a foam of blood and fear. From my severed tongue the defeat started, and the funeral procession set out. From my suppressed "No" the enemy got through, as well as the separation, the poverty, the hunger, the prison, the torturer, and the contemporary Arab collapse ... Briefly, if it weren't for my suppressed "No," half of me wouldn't be in the coffin and the other half dragging itself behind it. And my deprivation from my "No" made me not only into the victim and the spectator, the dead and the mourner, but also into a conspirator ... [T] he "No" citizen is, for the Arab thrones, a bigger danger than the Israeli danger, and a conspiracy worse than the imperialist conspiracies ... And until I recuperate my suppressed "No", the funeral procession will continue, with us dragging our tails behind it. (English translation quoted in Kassab 2010, p. 56 f.) 
The high degree of self-criticism and disillusionment in this text is characteristic for this dramatist's writings in the late 1970s. The metaphoric mini-narration clearly marks a turning point in his life that, according to the characteristics of a turning point quoted above, "tends to result in and correlate with, a heightened degree of self-awareness or self-consciousness on the part of the subject in question, an increased awareness that a decision has to be made" (Nünning and Sicks 2012, p. 7).

After his suicide attempt in November 1977, Wannūs did not write a single play for eleven years. He first broke his silence in fall 1989 with a play that was as celebrated as it was controversial - a play that attempted to relate to the Palestinian conflict from an Israeli viewpoint: al-Ightiṣāb [The Rape] (Wannūs 1996, vol. 2, p. 61 ff.). The Rape (originally published with Dār al-Ādāb, 1990) marks a turning point in Wannūs's dramatic writings. For the first time, the focus is placed on the individual, instead of the collective, and on the physical and psychological consequences and implications of political oppression. This drama deals with interpersonal problems, providing psychological studies, and achieving multidimensional characterization on both the Israeli and the Palestinian sides. The enemy that for decades had been represented in Syrian literature as a dehumanized monster and a united, homogenous block was now depicted as an individual suffering from Israeli state violence like its victims.

I would call Wannūs's new approach to theatre as a means of generating insights into individual and psychological phenomena "individualistic humanism." This form of humanism, which is closely tied to individual and psychological dimensions, is not without political implications. Indeed, the decision to point relentlessly at the devastating effects of violence and abuse on both victims and perpetrators is a deeply political act with a clear-cut humanistic meaning. Since Wannūs addresses the effects of violence on both sides of the Israeli-Palestinian conflict and, in so doing, breaks a taboo that had been maintained for many decades in Arab discourse, this humanistic meaning could be also called critical and Wannūs's approach could, therefore, be understood as a form of "critical humanism."

Viewing The Rape (Wannūs 1996, vol. 2) as an example of critical humanism allows us, furthermore, to perceive an intriguing link between Wannūs's thought and that of Frantz Fanon, who repeatedly stressed the importance of collective and individual responsibility on "a truly historical scale ... If nationalism is not explained, enriched, and deepened, if it does not very quickly turn into a social and political consciousness, into humanism, then it leads into a dead end" (Fanon 2004, p. 144). 
This humanism, which lies at the very root of both Fanon's and Wannūs's critical thinking, was also one of the main tenets of the Arab Spring uprisings, as exemplified in popular revolutionary slogans such as "al-sha'b yurīd isqāt al-nizām" ["the people want to bring down the regime/the system"]. Moreover, this vision of humanism links the perspectives of both Wannūs and Fanon with perspectives put forward in the context of the Arab Spring, and suggests the relevance of Fanon's argumentation to the process of engaging in a critical reflection about the dilemmas of the Arab societies in the late twentieth and early twenty-first centuries. Thus, what is being argued here is that The Rape may be understood as Wannūs's critical answer to the complete failure of a social and national humanism within both Israeli and Arab consciousness since 1948.

Sa dallāh Wannūs died in 1997, before he could witness the beginnings of the Syrian revolution. Nevertheless, Lebanese novelist and journalist Elias Khoury counts intellectuals and writers like him as forerunners of "a new culture, one which only fully emerged with today's generation of Syrian men and women who are bringing about a revolution from the heart of oppression and despair" (Khoury 2012, p. x). He considers his plays and essays as "the intellectual roots of the Syrian revolution" (Khoury 2012, p. xiv). Hence, Wannūs's idea of a critical humanism in the face of the devastating political circumstances in the Arab world seems to be an appropriate answer to the post-2011 situation as well.

In regard to dramatic changes in Wannūs's personal life, it is important to note that a second turning point after the first one in the late 1970s occurred in this dramatist's life and work: Wannūs came down with thyroid cancer in 1991. His terminal illness, diagnosed shortly after the Gulf War, lent his bleak words even greater weight. For his own part, Wannūs stylized himself as a victim of the political history of his era, portraying his illness and imminent death as the result of unsolved political problems:

It seems like we were destined to see a series of continuing blows. The last blow was so painful that I suspected it as the direct cause of my being stricken by cancer. The blow was the 1991 Gulf War which did away with the remaining hopes of the Arabs. It's no coincidence that I began to feel the tumor during the war, during the monstrous bombing carried out by the US against Iraq. (Wannūs in Amiralay 1997, min. 40:21-41:17).

In the following years, from 1991 to his death on May 15, 1997, he wrote, as he put it, against death. The perspective evident in his writing shifted after the outbreak of his illness, and along with it his literary techniques and characterization of figures. 


\section{From Didactic Theatre to Psychological Studies}

In contrast to the parable-like style of his politically accentuated didactic theatre, where the figures were examples, in the final phase of his creative life Wannūs addressed specific individual themes, exploring interpersonal problems, furnishing psychological studies, and achieving multidimensional characterization. Breaking more than one taboo, these plays are no less political and critical than his earlier texts of the 1960s and 1970s, however.

In an interview with Mari Elias in 1992 (p. 101), Wannūs explained a crucial turnaround in his work as stemming from the realization that, in the 1980s and early 1990s, political activism in the Arab world was hopeless. The opposition groups in society were marginalized, and established political forces were rotten to the core and hopelessly factional. Any belief in the possibility of changing the world through struggle, heroic acts, and martyrdom was suddenly revealed to be an illusion. In those years, which included the beginnings of the Lebanese Civil War and tragically culminating in the Israeli invasion of 1982, Wannūs bid farewell to the idea that had hitherto guided him: that the problems of the Arab world could be traced back to simple power relations in society.

The literary forms and themes of Wannūs's work changed accordingly. From consciously simplifying representations that aimed to ignite political change and restructure power relations, he now turned to an approach that sought to generate insights into problems of the individual in society as well as minority and gender issues. This new conception touches upon Said's concept of humanism: "Humanism is centered upon the agency of human individuality and subjective intuition, rather than on received ideas and approved authority" (Said 2003). ${ }^{1}$

More difficult than instigating a change of regime, Wannūs said in 1992, was "stir[ing] a society adhering to and petrified in superstition" (p. 101). This new style of drama led Wannūs to a kind of aesthetic liberation and self-discovery:

For the first time I have a sense of how writing can be a liberating act. Previously, I had certain ideas: I imposed a kind of self-censorship. An inner censorship which —as I imagined it—consisted in repressing everything that was of secondary importance, and left me to deal exclusively with the purportedly big questions. For the first time, I feel that writing is enjoyable. I was of the view that personal worries or individual problems were bourgeois, were superficial, unimportant affairs which one can put to one side. My whole interest was focused on grappling with and understanding history, and I thought - wrongly - that I had to avoid the traps of petit-bourgeois literature and go beyond all that was individual 
and personal. For this reason, I never felt as if entirely at one with myself in my work as playwright. (Wannūs 1992, p.101).

This quotation brings Wannūs quite close to Fadi Bardawil's description of the disenchantment of the 1960s' militant intellectuals in post-1967 discourse who "focused their analytical gaze inwards toward the social structures and culture of their societies" (2013, p. 92). Fadi Bardawil rereads the critical literature written after 1967 by the Syrian Marxist thinkers Yāsīn al-Ḥāiz and Șādiq Jalāl al- 'Azm, demonstrating how books like these reveal a kind of "turning of the critical gaze inwards, focusing on the level of social structures, culture, and values while seeking to move beyond analyses restricted to the political surface, such as those which theorized the defeat as a result of imperialism or the 'shortcomings of the Soviet Union"” (2013, p. 95).

This inward turn implied an essential transformation of the leftist intellectual's self-image. Wannūs's turn away from the belief that the problems and power relations of the Arab world might be solved and changed by the theatre of politicization could be placed within these Arab leftist discourses of political disenchantment-which in Wannūs's case did not set in until after Sadat's visit to Israel in 1977, ten years later. The Arab leftist intellectuals who shifted their critical gaze inwards towards a harsh critique of the backwardness of Arab society in the aftermath of 1967 did not lose their solidarity with the masses in the process. This new approach is aptly described by al- 'Azm in an interview from 1997:

What al-Hafez brought out for me was the importance of critically confronting the superstructures of thought, culture, heritage, and religion, which were impeding the economic, social, and political accomplishments of the Arab liberation movement. (quoted in Bardawil 2013, p. 95).

Al- 'Azm criticized the contradiction between the Arab liberation movement's "revolutionary" core economic and political agendas and the movement's own "conservative" superstructure. According to al- Azm, this contradiction was reproducing "values of ignorance, myth-making, backwardness, dependency, and fatalism" and thus "impeding the propagation of scientific values, secularism, enlightenment, democracy, and humanism" (al- 'Azm quoted in Bardawil 2013, p. 94). To my mind, this argument is exactly what motivated Sa'dallāh Wannūs to modify his dramatic style after his long literary silence in the late 1970s and 1980s.

Succeeding The Rape (Wannūs 1996, vol. 2) as his first endeavor of a new psychological approach, the five plays Wannūs wrote in the 1990s up to his death in 1997 reflect the author's new self-definition. ${ }^{2}$ These dramas no longer contain a simple and clearly political message or ideology which addresses "the people" or "the masses"; the addressee here is rather the individual, or a limited group of 
open-minded and attentive individuals who are astute enough to understand the veiled articulation of harsh political and social criticism.

In the last phase of his writing, and in the context of a litany of political setbacks in the Arab world, Wannūs renounced the idea that a change in power relations would automatically change society from within. This disenchantment of a committed leftist intellectual clearly reflects the new socio-political reality in 1979 and the two decades that followed. Egypt's peace treaty with Israel did indeed destroy or at least severely damage the imaginative possibilities of this Syrian author's understanding of intellectual and literary engagement. He no longer believed that the problems of the Arab world could be traced back to simple power relations in society and devoted himself instead to "to stir[ring up] a society adhering to and petrified in superstition" (Wannūs 1992, p. 101).

Thus, the political events of 1979 represent the parallel trends of societal change and personal transformations in a leading dramatist's biography and literary style. In Wannūs's autobiographical and intellectual self-narration, these political events are represented as a turning point that triggered a heightened degree of self-awareness and self-consciousness combined with an increased awareness that something has to be changed. The plays he published after his long literary silence until 1989 are Wannūs's critical answer to the complete failure of a social and national humanism within Arab consciousness in the postcolonial era. Here, the concept of critical humanism as a coping mechanism for ongoing injustice and backwardness in postcolonial Arab society and state, as coined by late Edward Said, nearly converges with Wannūs's position after his 1979 turning point: "humanism is the only—and I would go so far as saying the final—resistance we have against the inhuman practices and injustices that disfigure human history" (Said 2003).

The Lebanese author and journalist Elias Khoury (Ilyās Khūrī) also believes that only a blunt and unsparing self-criticism could enable the Arab world to deal adequately with the complex postcolonial situation. In an article, published in 2002 in the leftwing Beirut journal al-Tarīq, Khoury advocates a "third nahda/cultural awakening" (p. 28). He sees Said as a forerunner of a specific type of Arab intellectual, one who willingly assumes a highly visible public profile in intellectual opposition to the ruling powers. Comparable to the position taken by Wannūs, Khoury demands that the traditional roles of Arab intellectualism such as king, sheikh, poet, politician, officer, entrepreneur, or journalist be replaced by a new set of roles. In the spirit of Said's critique, a new oppositional practice and intellectual movement needs to be initiated, one that counters both the repression and the injustices of Arab governments and the xenophobic cultural and religious ideologies circulating in the Arab world. This new understanding of the public 
role of the Arab intellectual precisely fits Sa 'dallāh Wannūs's new orientation and outlook as an intellectual committed to a new critical humanism.

\section{Endnotes}

1. That the aspect of power is not excluded at all in this understanding becomes clear in Said's following sentences being much relevant for Wannūs as well: "Texts have to be read as texts that were produced and live on in the historical realm in all sorts of what I called worldly ways. But this by no means excludes power, since on the contrary I have tried to show the insinuations, the imbrications of power into even the most recondite of studies." (Said 2003).

2. Munamnamāt tārīkhiyya (Cairo 1994; Beirut 1996), TTuqūs al-ishārāt wa-l-taḥawwulāt (Beirut 1994), Yawm min zamāninā (Beirut 1995), Aḥlām shaqqiyya (Beirut 1995), Malhamat al-sirāb (Beirut 1996): all in al- 'Amāl al-kāmila vol. 2.

\section{References}

Abraham, M. 2007. Introduction: Edward said and after. toward a new humanism. Cultural Critique 67: 1-12.

Amiralay, Omar. 1997. Interview with Sa'dallāh Wannūs, "There are so many Things Still to Say". La Sept/ARTE 1997.

Bardawil, Fadi. 2013. The inward turn and its vicissitudes: Culture, society, and politics in post-1967 arab leftist critiques. In Local Politics and Contemporary Transformations in the Arab World. Governance Beyond the Center, Eds. M. Bouziane, C. Haders, and A. Hoffmann, 91-109. London: Palgrave Macmillan.

Fanon, Frantz. 2004. The Wretched of the Earth. Translated from French by Richard Philcox. New York, Grove Press. ("Les damnés de la terre". Paris 1961)

Khoury, E., and Ilyās Khūrī. 2002. Al-Nahḍa al-thālitha. Al-Ṭarīq 60 (1): 28-39.

Khoury, E. [Khūrī, Ilyās]. 2012. Foreword: Hope arising from despair. In Doomed by Hope. Essays on Arab Theatre, Ed. Eyad Houssami, S. x-xv. London: Pluto Press.

Kassab, Elizabeth Suzanne. 2010. Contemporary Arab Thought. Cultural Critique in Comparative Perspective. New York: Columbia University Press.

Nünning, A., and K.M. Sicks (eds.). 2012. Turning Points. Concepts and Narratives of Change in Literature and Other Media. Berlin: DeGruyter.

Said, Edward. 2003. Orientalism. CounterPunch. www.counterpunch.org/2003/08/05/orientalism. Accessed: 20 February 2020.

Wannūs, Sa dallāh. 1970. Bayānāt li-masraḥ 'arabī jad̄̄d. Beirut: Dār al-Ādāb. (reprint in Wannūs 1996:3).

Wannūs, Sa dallāh. 1992. Interview (with Mari Elias). Al-Ṭarīq: 101.

Wannūs, Sa dallāh. 1996. Al-A 'māl al-kāmila. Damascus: al-Ahālī. Vol. 1-3. 
Friederike Pannewick is professor of Modern Arabic Literature and Culture at Philipps-Universität Marburg (Germany) and co-director of the research field "Travelling Traditions: Comparative Perspectives on Near Eastern Literatures" within EUME/Forum Transregionale Studien in Berlin. She is co-editor of the book series Literatures in Context: Arabic-Persian-Turkish (Reichert) and has published extensively on modern Arabic literature and theatre.

Open Access This chapter is licensed under the terms of the Creative Commons Attribution 4.0 International License (http://creativecommons.org/licenses/by/4.0/), which permits use, sharing, adaptation, distribution and reproduction in any medium or format, as long as you give appropriate credit to the original author(s) and the source, provide a link to the Creative Commons license and indicate if changes were made.

The images or other third party material in this chapter are included in the chapter's Creative Commons license, unless indicated otherwise in a credit line to the material. If material is not included in the chapter's Creative Commons license and your intended use is not permitted by statutory regulation or exceeds the permitted use, you will need to obtain permission directly from the copyright holder.

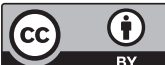

